\begin{tabular}{|l|l|l|l|l|l|}
\hline J. Tek. Ling & Vol.11 & No.1 & Hal. 105 - 116 & Jakarta, Januari 2010 & ISSN 1441-318X \\
\hline
\end{tabular}

\title{
EVALUASI KESESUAIAN LAHAN TANAMAN KAYU PUTIH KABUPATEN BURU, PROVINSI MALUKU
}

\author{
Sudaryono \\ Pusat Teknologi Lingkungan \\ Badan Pengkajian dan Penerapan Teknologi
}

\begin{abstract}
Maluku province is also famous as a producer of cajeput oil in Indonesia's number one, but its potential until now have not been optimally utilized in accordance with the carrying capacity of land for public welfare. Melaleuca Cajeputi Roxb have not managed intensively as industrial plants, consequently low production. Based on the results of land suitability assessment, pewilayahan eucalyptus trees on the island of Buru include areas that are not so large, that is 188,743 ha or $20.60 \%$ of the total area of the island of Buru, with the details:

Land is very suitable (S1) covering 54,832 hectares, or 6 percent of the total land area, mainly scattered in the northern part of Buru District, the floodplain physiography. Enough suitable land class (S2) on Buru Island reached a total area of 45,404 hectares of territory, with the main limiting factor is the rainfall and slope. Class marginal land suitable (S3) with severe limiting factor on regional conditions and slope roots reach a total area of 88,507 hectares.

Class of land not available for this moment (N1) reached 513,937 hectares with a very heavy barrier so that if the current efforts will be made to harm the environment or very costly. Spread primarily on physiography tectonics with sloping hills more than 25 percent and its height more than $400 \mathrm{~m}$ above sea level. Land Not Available forever (N2) are lands that have very severe limiting factor, so for good both physically and economically impossible to be undertaken.
\end{abstract}

Keywords: capability, suitability, land, cajuput oil

\section{PENDAHULUAN}

\subsection{Latar Belakang}

Provinsi Maluku merupakan salah satu provinsi di Kawasan Timur Indonesia (KTI) yang memiliki sumberdaya alam yang cukup besar. Selain dikenal sebagai penghasil komoditas yang bernilai ekonomi tinggi, seperti pala, lada, cengkeh (rempahrempah), Provinsi Maluku juga tersohor sebagai penghasil minyak kayu putih nomor satu di nusantara. Meskipun potensinya sampai saat ini belum dimanfaatkan secara optimal sesuai dengan kemampuan/daya dukung lahan untuk mensejahterakan

masyarakat.

Menurut Notohadiprawiro, T., harkat Iahan selalu berkenanan dengan suatu penggunaan tertentu maka suatu lahan yang berharkat baik untuk pertanian atau kepentingan lain ${ }^{1)}$. Mutu lahan dalam pengaruhnya atas kecocokan lahan untuk suatu macam penggunaan lahan tertentu. Daya dukung tergantung pada persentasi lahan yang dapat digunakan untuk pertanian yang berkelanjutan dan lestari, persentasi lahan ditentukan oleh kesesuaian lahan untuk 
tanaman hutan. Penelitian ini menggunakan satuan lahan sebagai satuan pemetaan yang disusun berdasarkan overlay Peta Tanah dan Peta Penggunaan Lahan ${ }^{2}$. Oleh karenanya agar pengembangan tanaman kayu putih sebagai tanaman unggulan kehutanan secara optimal, diperlukan suatu kajian wilayah yang mencakup aspek biofisik, ekonomi dan sosial sekaligus dengan mempertimbangkan faktor budaya masyarakat setempat untuk mengetahui wilayah pengembangan potensial, yang selanjutnya disusun dalam Peta Persebaran Tanaman Kayu Putih di Pulau Buru.

Di Pulau Buru dan gususan kepulauan lainnya disekitarnya, tanaman kayu putih belum dikelola secara intensif layaknya tanaman industri, tidak ada perawatan, tidak dipupuk, tidak ada upaya pencegahan terhadap hama dan penyakit tanaman, petani hanya mengandalkan terhadap kemurahan alam, tidak pernah dilakukan pemangkasan terhadap gulma yang mengganggu tanaman induk.

Tanaman kayu putih dapat digolongkan ke dalam tanaman yang dapat bertahan hidup pada kondisi lahan yang kurang subur, dengan iklim kering yang panjang, tahan terhadap suhu udara panas. Tanaman ini dapat ditemukan dari dataran rendah sampai pada ketinggian $400 \mathrm{~m}$ dpl., dapat tumbuh di dekat pantai di belakang hutan bakau, dengan tektur dari lempung berliat sampai liat berlempung, pada $\mathrm{pH}$ 4-7. Tanaman kayu putih ideal tumbuh pada iklim kering, curah hujan maksimum $2000 \mathrm{~mm}$ pertahun dengan suhu minimum $22^{\circ} \mathrm{C}$ dan suhu maksimum $32^{\circ} \mathrm{C}(3,4)$.

Tanaman kayu putih mempunyai daur biologis yang panjang, cepat tumbuh, dapat tumbuh subur pada tanah dengan draenase baik maupun jelek, dengan kadar garam tinggi maupun asam, tanaman kayu putih dapat dimanfaatkan sebagai tanaman penghijauan pada lahan dengan kemiringan kurang dari $15 \%$. Menurut laporan dari Dinas Kehutanan, Provinsi Maluku, luasan hutan tanaman kayu putih di Pulau Buru seluas 190.000 hektar dan 20.000 hektar di Pulau Seram (Bagian Barat), sedang menurut Dinas Perindustrian dan Perdagangan Provinsi Maluku, selain terdapat di kedua pulau tersebut, tanaman kayu putih dapat diketemukan pula di Kabupaten Maluku Tenggara Barat, seluas kurang lebih 20.000 hektar dan di Kabupaten Maluku Tengah seluas 5.000 hektar.

Langkah yang perlu dilakukan untuk mengoptimalkan luas hutan tanaman kayu putih dengan meningkatkan nilai ekonomi guna pemberdayaaan dan peningkatan kesejahteraan ekonomi rakyat, yaitu melalui revitalisasi sektor perhutanan dalam pemanfaatan lahan sesuai dengan daya dukungnya.

\subsection{Tujuan}

Tujuan penelitian ini adalah membuat peta kesesuaian lahan tanaman kayu putih dan merumuskan strategi pengembangan tanaman kayu putih sesuai dengan kondisi wilayah

\section{BAHAN DAN METODE}

\subsection{Bahan}

Pelaksanaan kegiatan studi evaluasi kesesuaian lahan tanaman kayu putih di Kabupaten Buru, dilaksanakan pada bulan Juni 2009 dengan melakukan berbagai liputan, seperti pengadaan dan pengumpulan data dari hasil kegiatan terdahulu, data/peta geologi, dan citra landsat.

Data yang dikumpulkan untuk penyusunan peta satuan lahan dan penggunaan lahan adalah:

1. Peta tata guna hutan kesepakatan Pulau Buru, skala 1:250.000 atau peta arahan tata ruang wilayah Provinsi Maluku dan Kabupaten Buru;

2. Peta Topografi yang ada (1:250.000) dan peta dasar skala 1:100.000 Pulau Buru 
3. Peta penggunaan lahan (land use) daerah Maluku skala 1:250.000

4. Peta Geologi Pulau Buru skala 1:250.000;

\subsection{Metode}

Lingkup kegiatan penyusunan peta kesesuaian lahan tanaman kayu putih, meliputi : (a) identifikasi dan karakterisasi sumberdaya lahan, (b) identifikasi penggunaan lahan/vegetasi penutup (present land use), dan (c) penyusunan peta pewilayahan kesesuaian lahan untuk tanaman kayu putih.

Kegiatan ini dilaksanakan melalui penelaahan data sekunder dan observasi lapangan. Data sekunder meliputi penelaahan data/peta dan informasi yang telah tersedia dan penyusunan peta satuan lahan. Penggunaan teknologi penginderaan jauh melalui analisis data citra satelit dilakukan untuk mengetahui penyebaran dan luas keadaan penggunaan lahan saat ini dalam rangka menentukan lahan potensial dan tersedia untuk pengembangan tanaman kayu putih.
Tahap pelaksanaan meliputi penyusunan peta satuan lahan skala 1:100.000 (peta interpretasi), analisis citra satelit untuk pembuatan peta penggunaan lahan saat ini, pengamatan/ verifikasi lapangan, penyusunan database sumberdaya lahan, evaluasi kesesuaian lahan, penyusunan peta dan ketersediaan lahan.

\section{HASIL DAN PEMBAHASAN}

\subsection{Kesuburan Tanah}

Keadaan kesuburan tanah di daerah penelitian diuraikan secara umum untuk beberapa unsur atau sifat tanah saja, yaitu $\mathrm{pH}$ (kemasaman tanah), kadar fosfat dan kalium. Kadar dari sifat-sifat tersebut berdasarkan pada data hasil analisis laboratorium tanah dari beberapa contoh tanah lapisan atas $(0-20 \mathrm{~cm})$ dan lapisan bawah $(20-50 \mathrm{~cm})$ yang dianggap dapat mewakili satuan peta tanah (SPT). Pengelompokan kadar $\mathrm{pH}$, Fosfat dan Kalium mengikuti kriteria penilaian data analisis tanah yang berlaku di Balai Penelitian Tanah.

Tabel 1. Kriteria Penilaian Fosfat, Kalium dan pH

\begin{tabular}{|l|c|l|l|l|l|}
\hline Sifat Tanah & $\begin{array}{l}\text { Sangat } \\
\text { Rendah (SR) }\end{array}$ & Rendah(R) & Sedang(S) & Tinggi(T) & $\begin{array}{l}\text { Sangat } \\
\text { Tinggi(ST) }\end{array}$ \\
\hline $\begin{array}{l}\mathrm{P}_{2} \mathrm{O}_{5} \mathrm{HCl} 25 \% \\
(\mathrm{mg} / 100 \mathrm{gr})\end{array}$ & $<15$ & $15-20$ & $21-40$ & $41-60$ & $>60$ \\
\hline $\begin{array}{l}\mathrm{K}_{2} \mathrm{O} \mathrm{HCl} 25 \% \\
(\mathrm{mg} / 100 \mathrm{gr})\end{array}$ & $<10$ & $10-20$ & $21-40$ & $41-60$ & $>60$ \\
\hline $\mathrm{P} 2 \mathrm{O} 5 \mathrm{Bray}(\mathrm{ppm})$ & $<10$ & $10-15$ & $16-25$ & $26-35$ & $>35$ \\
\hline $\mathrm{pH}\left(\mathrm{H}_{2} \mathrm{O}\right)$ & $\begin{array}{l}\text { Sangat } \\
\text { Masam }(\mathrm{SM})\end{array}$ & $\begin{array}{l}\text { Masam } \\
(\mathrm{M})\end{array}$ & $\begin{array}{l}\text { Agak } \\
\text { Masam } \\
(\mathrm{AM})\end{array}$ & Netral (N) & $\begin{array}{l}\text { Agak } \\
\text { Alkalis } \\
(\text { AA }) 3\end{array}$ \\
\hline & $<4,5$ & $4,5-5,5$ & $5,6-6,5$ & $6,6-7,5$ & $7,6-8,5$ \\
\hline
\end{tabular}




\section{1) Kemasaman Tanah $(\mathrm{pH})$}

Kemasaman tanah $(\mathrm{pH})$ tanah dapat mempengaruhi ketersediaan hara tanah dan bisa menjadi faktor yang berhubungan dengan kualitas tanah. $\mathrm{pH}$ sangat penting dalam menentukan aktivitas dan dominasi mikroorganisme tanah yang berhubungan dengan proses-proses yang sangat erat kaitannya dengan siklus hara, penyakit tanaman, dekomposisi dan sintesa senyawa kimia organik dan transpor gas ke atmosfir oleh mikroorganisme ${ }^{5)}$.

Pada reaksi tanah agak masam hingga netral ( $\mathrm{pH} 5,6$ - 7,5) kelarutan unsurunsur hara berada dalam keadaan optimum, karena kemampuan tanah mengikat hara berada paling rendah. Dengan demikian tanah-tanah yang bereaksi agak masam hingga netral relatif lebih menguntungkan untuk tanaman dan pemupukan. Secara garis besar keadaan reaksi tanah di Kabupaten Buru, Provinsi Maluku dapat dikelompokkan kedalam tanah sangat masam $(\mathrm{pH}<4,5)$, masam $(\mathrm{pH} 4,5-5,5)$, agak masam $(\mathrm{pH} \mathrm{5,6-}$ $6,5)$ dan netral $\left.(\mathrm{pH} 6,6-7,5)^{6}\right)$.

Kemasaman tanah di daerah penelitian dibedakan atas kemasaman tanah lapisan atas $(0-20 \mathrm{~cm})$ dan kemasaman tanah lapisan bawah $(20-50 \mathrm{~cm})$. Kemasaman tanah di Pulau Buru pada lapisan atas maupun lapisan bawah bervariasi sangat masam sampai agak masam, kecuali pada tanahtanah dari bahan berkapur atau batukapur lebih tinggi yakni agak masam sampai netral. Namun jika dilihat secara keseluruhan, $\mathrm{pH}$ tanah di Pulau Buru cenderung lebih tinggi hal ini berkaitan dengan sifat bahan induk yang lebih basis di Pulau Buru dan iklim yang lebih kering, sehingga proses pelapukan berlangsung lambat.

Untuk menunjang pertumbuhan tanaman pada lahan kering, khususnya tanaman tahunan, lahan-lahan yang termasuk sangat masam dan masam, memerlukan perbaikan yaitu dengan cara pengapuran, atau dengan pemberian bahan organik yang berasal dari pupuk kompos (kandang).
Lahan sangat masam perlu dikapur dengan takaran 2,5-3 ton per ha, sedangkan lahan masam cukup dikapur dengan takaran 0,52 ton per ha, dan lahan agak masam tidak memerlukan pengapuran ${ }^{2}$.

\section{2) Bahan Organik dan Nitrogen}

Penambahan bahan organik kedalam tanah lebih kuat pengaruhnya kearah perbaikan sifat-sifat tanah, khususnya untuk meningkatkan unsur hara di dalam tanah. Kandungan bahan organik di wilayah studi umumnya rendah $(1-2) \%$ akibat dari pencucian basa berlangsung intensif, dan sebagian terbawa erosi. Pada tanah yang mepunyai horizon kandik, kesuburan alami hanya ditentukan pada bahan organik di lapisan atas, sehingga kapasitas pertukaran kation hanya tergantung pada kandungan bahan organik dan fraksi liat(). Oleh karena itu untuk meningkatkan produktivitas tanah hanya dapat dilakukan melalui perbaikan tanah melalui pemupukan dan pemberian bahan organik.

Bahan organik adalah merupakan sumber $\mathrm{N}$ utama di dalam tanah dan berperan cukup besar dalam proses perbaikan sifat fisika, kimia dan biologi tanah. Kadar N tanah biasanya dikategorikan sebagai indikator untuk menentukan dosis pupuk Urea. Fungsi nitrogen dalam tanah adalah untuk memperbaiki pertumbuhan vegetatif tanaman. Tanaman yang tumbuh pada tanah yang cukup N, berwarna lebih hijau. Kadar $\mathrm{N}$ tanah di wilayah studi tergolong sangat rendah sampai sedang.

\section{3) Kandungan $\mathrm{P}$ dan $\mathrm{K}$ Tersedia}

Fosfor $(P)$ merupakan unsur hara esensiil bagi tanaman. Unsur hara fosfor (P) merupakan hara makro penting setelah unsur hara $\mathrm{N}$, diserap dari tanah dalam bentuk $\mathrm{H}_{2} \mathrm{PO}_{4}$ - dan atau $\mathrm{HPO}_{42}{ }^{-}$. Kadar hara $P$-tersedia yang tinggi akan menguntungkan bagi tanaman sehingga tanah-tanah demikian cenderung lebih subur. Tidak ada unsur lain yang dapat menggantikan 
fungsinya di dalam tanaman, sehingga tanaman harus mendapatkan unsur hara $P$ secara cukup untuk pertumbuhannya. Fungsi penting fosfor di dalam tanaman yaitu dalam proses fotosintesis, respirasi, transfer dan penyimpanan energi, pembelahan dan pembesaran sel serta proses-proses yang lainnya.

Ketersediaan $\mathrm{P}$ dalam tanah bagi tanaman dipengaruhi oleh kemasaman tanah. Ketersediaan optimum dari unsur hara ini bagi tanaman diperoleh pada $\mathrm{pH}$ $5,5-7,0$. Bentuk ion $\mathrm{P}$ yang terdapat dalam tanah tergantung dari $\mathrm{pH}$ larutan tanah, bila tanah bereaksi basa ion $\mathrm{HPO}_{42}$ - merupakan ion $\mathrm{P}$ yang dominan, dengan menurunnya $\mathrm{pH}$ tanah, bentuk $\mathrm{H}_{2} \mathrm{PO}_{4}$ - dan $\mathrm{HPO}_{42}$ - akan dijumpai dalam larutan tanah, sedangkan apabila keadaan kemasaman bertambah $\mathrm{H}_{2} \mathrm{PO}_{4}-$ akan semakin dominan. Tanaman mengambil fosfor dari dalam larutan tanah dalam bentuk ortho fosfat primer $\left(\mathrm{H}_{2} \mathrm{PO}_{4}\right)$, mekanismenya melalui proses difusi. Kecepatan penyediaannya dari tanah ke akar dipengaruhi oleh koefisien difusi, kosentrasi hara fosfor dalam larutan tanah, dan kapasitas penyangga tanah.

Pada kisaran $\mathrm{pH} \mathrm{6,0} \mathrm{-} \mathrm{7,3} \mathrm{merupakan}$ $\mathrm{pH}$ optimum dimana $\mathrm{P}$ tersedia dalam jumlah maksimal karena pada kondisi ini kemampuan tanah mengikat $P$ adalah paling rendah. Pada $\mathrm{pH}$ yang semakin rendah (sangat masam) atau semakin tinggi (sangat alkalis) jumlah P-tersedia semakin sedikit, karena semakin banyak $\mathrm{P}$-tersedia diikat menjadi senyawa-senyawa yang sukar larut ${ }^{6)}$.

Keadaan kadar fosfat pada tanah di daerah Pulau Buru bervariasi sangat rendah sampai sangat tinggi. Pada umumnya tanah lapisan bawah kadar fosfor lebih rendah dari lapisan atasnya, hal ini diduga karena adanya pengaruh dari sifat bahan induknya yang berasal dari batuan sedimen masam dan batuan metamorf, terutama sekis. Secara keseluruhan tanah di Kabupaten Buru tergolong kurang subur dengan kandungan
C-organik rendah (berkisar antara 1 - 2 $\%$ ), bahkan ada beberapa wilayah yang C-organiknya kurang dari $1 \%{ }^{7}$.

\section{4) Kalium ( K )}

Kalium merupakan unsur hara ketiga setelah $\mathrm{N}$ dan $\mathrm{P}$ yang dibutuhkan tanaman dalam jumlah banyak dan berperan penting dalam proses fotosintesa, pembentukan karbohidrat dan protein. Pemupukan kalium pada lahan pertanian kering baik padi maupun jagung serta umbi-umbian menunjukkan hasil yang nyata, apabila pupuk nitrogen dan fosfor juga diberikan dalam jumlah yang cukup, tetapi bila terjadi konsumsi kalium yang berlebihan, maka konsentrasi kalium dalam jaringan tumbuhan meningkat, akibatnya translokasi kation lain terutama $\mathrm{Mg}$ akan terganggu sehingga terjadi penurunan kadar $\mathrm{Mg}$ dalam daun sedemikian rendahnya sehingga fotosintesa akan terganggu ${ }^{5}$. Sebaliknya bila kadar Mg dalam tanah dalam jumlah tinggi, maka kadar kalium yang tersedia bagi tanaman akan menurun, karena difiksasi oleh koloid tanah atau tercuci bersama air drainase (curah hujan tinggi).

Kadar hara $\mathrm{K}$ pada tanah-tanah di daerah Pulau Buru umumnya sangat tinggi, hal ini dimungkinkan karena berasal dari bahan batuan metamorf dan volkan tua walaupun kemungkinan terdapat kadar kalium sangat rendah dan rendah.

\subsection{Kesesuaian Lahan}

Evaluasi kesesuaian lahan untuk komoditas Kayu Putih (Melaleuca leucadendra) dilakukan terhadap peta satuan lahan dengan skala 1:100.000. Evaluasi kesesuaian lahan dilakukan dengan cara mencocokkan antara karakteristik lahan dan persyaratan tumbuh tanaman. Data karakteristik lahan diperoleh dari hasil kompilasi data penelitian terdahulu dan survei lapangan.

Dari hasil studi 2), struktur klasifikasi kesesuaian lahan dibedakan antara lahan 
yang tergolong sesuai $(\mathrm{S})$ dan lahan yang tidak sesuai (N). Selanjutnya kelas dibedakan berdasarkan tingkat kecocokan, yaitu lahan yang tergolong ordo sesuai (S) dibedakan ke dalam tiga kelas, yaitu: lahan sangat sesuai (S1), cukup sesuai (S2), dan sesuai marginal (S3). Sedangkan untuk Ordo tidak sesuai (N) biasanya diurai dalam 2 kelas, yaitu (N1) tidak sesuai untuk saat ini, dan (N2) tidak sesuai untuk selamanya. Subkelas adalah keadaan tingkatan dalam kelas kesesuaian lahan. Kelas kesesuaian lahan dibedakan menjadi subkelas berdasarkan kualitas dan karakteristik lahan (sifat-sifat tanah dan lingkungan fisik lainnya) yang menjadi faktor pembatas terberat, misal Subkelas S3rc, xs sesuai marginal dengan pembatas kondisi perakaran ( $\mathrm{rc}=$ rooting condition) dan bahaya bahan sulfidik/pirit (xs). dan unit 2. Unit 1 kedalaman efektif sedang (50-75 cm), dan Unit 2 kedalaman efektif dangkal $(<50 \mathrm{~cm})$. Dalam praktek evaluasi lahan pada kegiatan ini (skala 1:100.000), kesesuaian lahan pada kategori unit tidak digunakan. Kelas kesesuaian lahan secara fisik dibedakan atas 5 kelas, seperti yang terlihat dalam Tabel 2 .

\subsection{Kesesuaian Lahan Kayu Putih Pulau Buru}

Ekstraksi hasil analisis kesesuaian lahan untuk kayu putih disajikan dalam Tabel 3 , sedangkan penyebaran dari masingmasing kelas kesesuaian disajikan dalam Gambar 1. Tabel 3 menjelaskan tentang kelas kesesuaian, faktor pembatas utama

Tabel 2 : Kelas Kesesuaian Lahan Kualitatif (Biofisik)

\begin{tabular}{|l|l|l|l|}
\hline Kelas & Simbol & Nama & Pengertian \\
\hline 1 & S1 & Sangat sesuai & $\begin{array}{l}\text { Tanpa atau sedikit pembatasan untuk } \\
\text { penggunaanya }\end{array}$ \\
\hline 2 & S2 & Cukup sesuai & Tingkat Pembatasan sedang untuk penggunaanya \\
\hline 3 & S3 & Sesuai marjinal & Tingkat pembatas berat untuk penggunaanya \\
\hline 4 & N1 & Tidak sesuai & Peggunaanya tidak memungkinkan untuk saat ini \\
\hline 5 & N2 & Tidak Sesuai & $\begin{array}{l}\text { Peggunaanya tidak memungkinkan secara } \\
\text { permanen }\end{array}$ \\
\hline
\end{tabular}

Unit adalah keadaan tingkatan dalam subkelas kesesuaian lahan, yang didasarkan pada sifat tambahan yang berpengaruh dalam pengelolaannya. Contoh kelas S3rc1 dan S3rc2, keduanya mempunyai kelas dan subkelas yang sama dengan faktor penghambat sama yaitu kedalaman efektif, yang dibedakan ke dalam unit 1 dan luasan dari masing-masing kelas. Sebagian besar lahan Pulau Buru masuk dalam katagori Tidak Sesuai $(\mathrm{N})$, yaitu mencapai luasan 724.409 hektar atau sekitar 79 persen luas wilayah. Sedangkan Luas lahan yang masuk katagori ordo Sesuai (S) seluas 188.744 hektar atau 21 persen luas wilayah. 
Tabel 3 : Kesesuaian Lahan untuk Kayu Putih di Pulau Buru

\begin{tabular}{|l|l|l|l|l|}
\hline Kode & Kelas Kesesuaian & Faktor Pembatas Utama & Luasan & Persentasi \\
\hline S1 & Sangat Sesuai & - & 54.832 & 6,0 \\
\hline S2c & Cukup Sesuai & Curah Hujan & 17.248 & 1,9 \\
\hline S2s & Cukup Sesuai & Kelerengan & 28.156 & 3,1 \\
\hline S3r & Sesuai Marjinal & Perakaran & 24.393 & 2,7 \\
\hline S3s & Sesuai Marjinal & Kelerengan & 64.114 & 7,0 \\
\hline N1s & Tidak Sesuai saat ini & Kelerengan & 176.283 & 19,3 \\
\hline N1e & Tidak Sesuai saat ini & Ketinggian & 61.889 & 6,8 \\
\hline N1es & Tidak Sesuai saat ini & Ketinggian, Kelerengan & 275.764 & 30,2 \\
\hline N2e & Tidak Sesuai Selamanya & Ketinggian & 87.433 & 9,6 \\
\hline N2es & Tidak Sesuai Selamanya & Ketinggian, Kelerengan & 123.039 & 13,5 \\
\hline Total Luasan & & 913.152 & 100,00 \\
\hline
\end{tabular}

Lahan sangat sesuai (S1) untuk kayu putih seluas 54.832 hektar atau 6\% dari total luas wilayah, terutama tersebar di wilayah Kabupaten Buru bagian utara, pantai Waplau, sebagian di Kecamatan Air Buaya, pada fisiografi dataran banjir. Kelas Iahan cukup sesuai (S2) di Pulau Buru mencapai total luasan 45.404 hektar atau sekitar 5 persen dari luas wilayah, tersebar disekitar Kecamatan Batubual, Namlea dan Kecamatan Airbuaya. Faktor pembatas utama yang menjadi kendala utama apabila kelas lahan ini akan diusakan untuk tanaman kayu putih adalah curah hujan dan kelerengan. Kelas lahan cukup sesuai dengan faktor pembatas curah hujan mencapai luasan 17.248 hektar terutama tersebar di bagian selatan Pulau Buru yang mempunyai curah hujan lebih dari 2000 $\mathrm{mm} /$ tahun. Sedangkan lahan cukup sesuai dengan faktor pembatas kelerengan (slope) mencapai luasan 28.156 hektar terutama tersebar pada fisiografi dataran tektonik yang mempunyai mikro-rilief bergelombang. Penyebaran terluas terutama di sebelah tenggara Pulau Buru, memanjang/paralel dengan pantai sampai beberapa kilometer ke pedalaman.

Kelas lahan sesuai marjinal (S3) dengan faktor pembatas berat pada kondisi daerah perakaran dan kelerengan mencapai luasan total 88.507 hektar atau sekitar 10 persen luas wilayah. Kelas Iahan ini dengan faktor pembatas kondisi perakaran mempunyai luasan 24.393 hektar terutama tersebar pada fisiografi teras-teras marin yang mempunyai tekstur pasir. Sedangkan faktor pembatas kelerengan dengan tingkat berat pada kelas lahan sesuai marjinal dijumpai pada lahan dengan luasan 64.114 hektar tersebar pada fisiografi perbukitan

tektonik. Lereng pada fisiografi ini berkisar antara 15-25 persen, sehingga akan membahayakan lingkungan terutama erosi lahan apabila akan diusahakan budidaya kayu putih.

Kelas Iahan Tidak Sesuai untuk saat ini (N1) adalah lahan-lahan yang mempunyai faktor pembatas sangat berat sehingga apabila akan diusahakan saat ini akan membahayakan lingkungan atau membutuhkan biaya sangat besar tidak sebanding dengan pendapatan yang akan diperoleh. Luas lahan yang masuk dalam katagori kelas N1 mencapai 513937 hektar atau sekitar 56 persen luas wilayah dengan factor pembatas utama kelerengan dan ketinggian atau kombinasi 
dari dua pembatas tersebut. Penyebarannya terutama pada fisiografi perbukitan tektonik dengan kelerengan lebih dari 25 persen dan ketinggiannya lebih dari $400 \mathrm{~m}$ dari permukaan laut.

Lahan Tidak Sesuai selamanya (N2) adalah lahan-lahan yang mempunyai faktor pembatas sangat berat, sehingga untuk selamanya baik secara fisik maupun ekonomi tidak memungkinkan untuk diusahakan. Luas lahan yang masuk katagori ini mencapai 210472 hektar atau sekitar 23\% dari luas wilayah. Faktor pembatas utama adalah kelerengan, ketinggian dan juga kondisi perakaran terutama pada daerah berkapur. Penyebarannya terutama pada fisiografi pegunungan tektonik di bagian tengah Pulau Buru dan pada fisiografi pegunungan Karst di bagian barat daya pulau.

\section{KESIMPULAN}

Dari hasil kegiatan ini dapat dikemukakan beberapa kesimpulan berdasarkan kondisi biofisik daerah, sebagai berikut:

1. Kesuburan tanah di lokasi kegiatan berdasarkan beberapa unsur atau sifat tanah, yaitu $\mathrm{pH}$ (kemasaman tanah), kadar fosfat, kalium dan kejenuhan basa. Menunjukkan bahwa $\mathrm{pH}$ tanah di Pulau Buru cenderung asam sampai netral. Keadaan kadar fosfat pada tanah di Pulau Buru bervariasi sangat rendah sampai sangat tinggi. Pada umumnya tanah lapisan bawah kadar fosfor lebih rendah dari lapisan atasnya, hal ini diduga karena adanya pengaruh dari sifat bahan induknya yang berasal dari batuan sedimen masam dan batuan metamorf, terutama sekis. Kadar hara K pada tanah-tanah di daerah Pulau Buru umumnya sangat tinggi.

2. Berdasarkan hasil penilaian kesesuaian lahan secara biofisik, penggunaan lahan eksisting dan mempertimbangkan status kawasan hutan dari peta kawasan hutan, maka pewilayahan tanaman kayu putih di Pulau Buru adalah mencakup areal tidak begitu luas, yakni hanya 188.743 ha atau 20,60 \% dari luas total Pulau Buru. Rincian pewilayahan tersebut adalah sebagai berikut:

Lahan sangat sesuai (S1) untuk kayu putih seluas 54.832 hektar atau 6 persen dari total luas wilayah, terutama tersebar di wilayah Kabupaten Buru bagian utara, pada fisiografi dataran banjir. Kelas lahan cukup sesuai (S2) di Pulau Buru mencapai total luasan 45.404 hektar wilayah, tersebar disekitar Kecamatan Batubual, Namlea dan Kecamatan Airbuaya. Faktor pembatas utama yang menjadi kendala utama apabila kelas lahan ini akan diusakan untuk tanaman kayu putih adalah curah hujan dan kelerengan.

Kelas lahan sesuai marjinal (S3) dengan faktor pembatas berat pada kondisi daerah perakaran dan kelerengan mencapai luasan total 88.507 hektar. Kelas lahan ini dengan faktor pembatas kondisi perakaran mempunyai luasan 24.393 hektar terutama tersebar pada fisiografi teras-teras marin yang mempunyai tekstur pasir. Sedangkan faktor pembatas kelerengan dengan tingkat berat pada kelas lahan sesuai marjinal dijumpai pada lahan dengan luasan 64.114 hektar tersebar pada fisiografi perbukitan tektonik. Lereng pada fisiografi ini berkisar antara $15-25 \%$, sehingga akan membahayakan lingkungan terutama erosi lahan apabila akan diusahakan budidaya kayu putih.

Kelas Iahan Tidak Sesuai untuk saat ini (N1) adalah lahan-lahan yang mempunyai faktor pembatas sangat berat sehingga apabila akan diusahakan saat ini akan membahayakan lingkungan atau membutuhkan biaya sangat besar tidak sebanding dengan pendapatan yang akan diperoleh. Luas lahan yang masuk 
dalam katagori kelas N1 mencapai 513937 hektar dengan faktor pembatas utama kelerengan dan ketinggian atau kombinasi dari dua pembatas tersebut. Penyebarannya terutama pada fisiografi perbukitan tektonik dengan kelerengan lebih dari 25 persen dan ketinggiannya lebih dari $400 \mathrm{~m}$ dari permukaan laut.

Lahan Tidak Sesuai selamanya (N2) adalah lahan-lahan yang mempunyai faktor pembatas sangat berat, sehingga untuk selamanya baik secara fisik maupun ekonomi tidak memungkinkan untuk diusahakan. Luas lahan yang masuk katagori ini mencapai 210472 hektar atau sekitar 23 persen dari luas wilayah. Faktor pembatas utama adalah kelerengan, ketinggian dan juga kondisi perakaran terutama pada daerah berkapur. Penyebarannya terutama pada fisiografi pegunungan tektonik di bagian tengah Pulau Buru dan pada fisiografi pegunungan Karst di bagian barat daya pulau.

\section{DAFTAR PUSTAKA}

1. Notohadiprawiro, T., 1991. Kemampuan dan Kesesuaian Lahan: Pengertian dan Penetapannya. IImu Tanah, Universitas Gadjah Mada.

2. Peta Pewilayahan Komoditas Unggulan Perkebunan di Pulau Buru, Pulau Seram dan sekitarnya, 2008. Dinas Pertanian, Provinsi Maluku.

3. AsianBrain.com. Syarat Tumbuh Kayu Putih : Kayu Putih dan Manfaatnya.

4. Budidaya Kayu Putih: Upaya Menggali Potensi Lahan, 2009. Dinas Pertanian dan Kehutanan Kabupaten Sleman, DI. Yogyakarta.

5. Notohadiprawiro, T., (1986). Ultisol, Fakta dan Implikasi Pertaniannya. Bulletin Pusat Penelitian Marihat. No. 6.

6. Sofyan Ritung, Wahyunto, Fahmuddin Agus dan Hapid Hidayat, 2007. Panduan Kesesuaian Lahan: dengan contoh Peta Arahan Kabupaten Aceh Barat. Balai Penelitian Tanah dan World Agroforestry Centre, Bogor.

7. Zeng-Yei Hsru and Zueng-Sang Chen (2001). Quantifying Soil Hydromorphology of a Rice-Growing Utisol Toposequence in Taiwan. Soil Science of America Journal 65:270278. 
Lampiran 1 Tabel : Kriteria Kesesuaian Lahan untuk Tanaman Kayu Putih

\begin{tabular}{|c|c|c|c|c|c|}
\hline \multirow{2}{*}{\begin{tabular}{|l|} 
Karakteristik Lahan \\
Temperatur Rata-rata Tahunan (OC)
\end{tabular}} & \multicolumn{5}{|c|}{ Kelas Kesesuaian Lahan } \\
\hline & S1 & S2 & S3 & N1 & N2 \\
\hline & $21-35$ & $\mathrm{Td}$ & $\mathrm{Td}$ & $\mathrm{Td}$ & $\begin{array}{l}>35 \\
<21\end{array}$ \\
\hline $\begin{array}{lc}\text { Ketersediaan Air } & (\mathrm{w}) \\
\text { - Bulan Kering } & (<75 \mathrm{~mm}) \\
\text { - Curah hujan/tahun } & (\mathrm{mm})\end{array}$ & $\begin{array}{c}2-4 \\
1200-1500\end{array}$ & $\begin{aligned} & <2 \\
> & 1600 \\
800- & <1200\end{aligned}$ & $\begin{array}{c}>4 \\
<800\end{array}$ & $\mathrm{Td}$ & $<600$ \\
\hline $\begin{array}{l}\text { Media Perakaran } \\
\text { - Drainase Tanah }\end{array}$ & $\begin{array}{l}\mathrm{s} \text { a } \mathrm{n} g \text { a } \mathrm{t} \\
\text { tambat }\end{array}$ & Terhambat & $\begin{array}{l}\text { agak cepat, } \\
\text { agak tambat } \\
\text { cepat }\end{array}$ & Cepat & $\begin{array}{l}\text { Sangat } \\
\text { cepat } \\
\text { Tambat }\end{array}$ \\
\hline - Tekstur & $\begin{array}{l}\text { L,SCL,SiL,Si, } \\
\text { CL,SC,SiCL }\end{array}$ & LS,SL,SC,C & $\begin{array}{l}\text { LS,LS,SiC Str } \\
\text { C, liat massif }\end{array}$ & $\mathrm{Td}$ & $\begin{array}{l}\text { Kerikil, } \\
\text { pasir }\end{array}$ \\
\hline $\begin{array}{l}\text { - Kedalaman efektif } \\
\text { - Gambut } \\
\text { a. Kematangan } \\
\text { b. Ketebalan }\end{array}$ & $\begin{array}{c}>100 \\
- \\
-\end{array}$ & $\begin{array}{l}75-100 \\
\text { Saprik } \\
<100\end{array}$ & $\begin{array}{c}50-<75 \\
\text { Hemik } \\
100-150\end{array}$ & $\begin{array}{l}\text { Hemik-Fibrik } \\
>150-200\end{array}$ & $\begin{array}{l}<50 \\
\text { Febrik } \\
>200\end{array}$ \\
\hline Retensi hara & $7.0-7,5$ & $7.6-8.0$ & $.6-8.5$ & $\mathrm{Td}$ & .8 .5 \\
\hline - C Organik & & $6.0-7.0$ & $5.0-6.0$ & & $<5.0$ \\
\hline Keragaman & & & & & \\
\hline$(\mathrm{mmhos} / \mathrm{cm})$ & $<4$ & $4-8$ & $8-12$ & $12-15$ & $>15$ \\
\hline Toksisitas & $>125$ & $75-125$ & $<75$ & & \\
\hline - Kedalaman Sulfidik & & & & & \\
\hline Terrain/potensi mekanisasi & & & & & \\
\hline - Lereng & $<8$ & $8-15$ & $>15-30$ & $>30-50$ & $>50$ \\
\hline - Batuan permukaan & $<3$ & $3-15$ & $>15-40$ & $\mathrm{Td}$ & $>40$ \\
\hline - Singkapan Batuan & $<2$ & $2-10$ & $>10-25$ & $>25-40$ & $>40$ \\
\hline
\end{tabular}


Tabel : Hasil Analisis Tanah Beberapa Jenis Tanah Pulau Buru

\begin{tabular}{|c|c|c|c|c|c|c|c|c|c|c|c|c|c|c|c|c|c|}
\hline \multirow[t]{3}{*}{ No. } & \multirow{3}{*}{$\begin{array}{l}\text { No m or } \\
\text { Contoh }\end{array}$} & \multirow{3}{*}{$\begin{array}{l}\text { Klasifikasi } \\
\text { Tanah }\end{array}$} & \multirow{3}{*}{$\begin{array}{l}\text { Keda- } \\
\text { laman } \\
\text { Tanah }\end{array}$} & \multicolumn{4}{|c|}{ Tektur } & \multirow{2}{*}{\multicolumn{3}{|c|}{$\begin{array}{l}\text { Ekstrak 1:5 } \\
\mathrm{pH}\end{array}$}} & \multicolumn{7}{|c|}{ Terhadap contoh kering $1050 \mathrm{C}$} \\
\hline & & & & \multirow{2}{*}{$\begin{array}{l}\text { Pasir } \\
\%\end{array}$} & \multirow{2}{*}{$\begin{array}{l}\text { Debu } \\
\%\end{array}$} & \multirow{2}{*}{$\begin{array}{l}\text { Liat } \\
\%\end{array}$} & \multirow[t]{2}{*}{ Kelas } & & & & \multirow[t]{2}{*}{$\mathrm{DHL}$} & \multicolumn{6}{|c|}{ Bahan Organik } \\
\hline & & & & & & & & $\mathrm{H}_{2} \mathrm{O}$ & Kelas & $\mathrm{KCl}$ & & C & Kelas & $\mathrm{N}$ & Kelas & $\mathrm{C} / \mathrm{N}$ & Kelas \\
\hline & P. Buru & & & & & & & & & & & & & & & & \\
\hline 1. & ZW-43/I & & $0-15$ & 20 & 71 & 9 & SL & 4.7 & M & 4.3 & & 1.17 & $\mathrm{R}$ & 0.09 & SR & 13 & $\mathrm{~s}$ \\
\hline 2. & ZW-43/II & Typic & $15-25$ & 15 & 76 & 9 & SL & 4.8 & M & 4.2 & & 0.91 & SR & 0.07 & SR & 13 & 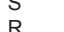 \\
\hline 3. & ZW-43/III & Fluvaquents & $25-60$ & 13 & 76 & 11 & SL & 4.8 & M & 4.3 & & 0.51 & SR & 0.05 & SR & 10 & \\
\hline 4. & ZW-36/I & $\begin{array}{l}\text { Lithic } \\
\text { Udorthents }\end{array}$ & $0-15$ & 46 & 36 & 18 & L & 7.3 & $N$ & 6.9 & & 4.55 & $T$ & 0.46 & $S$ & 10 & $\mathrm{R}$ \\
\hline 5 & ZW-38/I & $\begin{array}{l}\text { Lithic } \\
\text { Udorthents }\end{array}$ & $0-25$ & 44 & 33 & 23 & L & 5.8 & AM & 5.1 & & 1.63 & $\mathrm{R}$ & 0.14 & $\mathrm{R}$ & 12 & $\mathrm{~S}$ \\
\hline 6. & ZW-39/I & Lithic & $0-15$ & 53 & 23 & 24 & SCL & 4.6 & $M$ & 3.8 & & 0.90 & SR & 0.07 & SR & 13 & $S$ \\
\hline 7. & ZW-39/II & Udorthents & $15-30$ & 41 & 39 & 20 & L & 4.7 & $\mathrm{M}$ & 4.0 & & 0.33 & SR & 0.03 & SR & 11 & S \\
\hline 8. & ZW-10/I & Typic & $0-20$ & 91 & 4 & 5 & S & 7.4 & $\mathrm{~N}$ & 7.2 & & 3.49 & $\mathrm{~T}$ & 0.34 & $\mathrm{R}$ & 10 & $\mathrm{R}$ \\
\hline 9. & ZW-10/II & Udorthents & $20-70$ & 94 & 1 & 5 & $S$ & 8.2 & AA & 7.3 & & 0.60 & SR & 0.05 & SR & 12 & $\mathrm{~S}$ \\
\hline 10 & ZW-22/I & $\begin{array}{l}\text { Typic } \\
\text { Udorthents }\end{array}$ & $0-15$ & 45 & 41 & 14 & $S$ & 4.4 & SM & 3.8 & & 1.88 & $\mathrm{R}$ & 0.13 & $\mathrm{R}$ & 14 & $\mathrm{~S}$ \\
\hline 11. & ZW-29/I & Typic & $0-20$ & 78 & 12 & 10 & $\mathrm{SL}$ & 4.9 & M & 4.0 & & 0.18 & SR & 0.02 & SR & 9 & $\mathrm{R}$ \\
\hline 12. & ZW-29/II & Udorthents & $20-50$ & 88 & 6 & 6 & 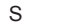 & 5.0 & M & 4.1 & & 0.09 & SR & 0.01 & $\mathrm{SR}$ & 9 & $\mathrm{R}$ \\
\hline 13. & ZW-29/III & & $50-90$ & 87 & 6 & 7 & SL & 5.1 & M & 4.0 & & 0.08 & SR & 0.01 & SR & 8 & $\mathrm{R}$ \\
\hline 14. & ZW-4/I & Typic & $0-20$ & 1 & 81 & 18 & Sil & 4.3 & SM & 4.0 & & 1.53 & $\mathrm{R}$ & 0.11 & $\mathrm{R}$ & 14 & $\mathrm{~S}$ \\
\hline 15. & ZW-4/II & & $20-40$ & 6 & 76 & 18 & Sil & 4.7 & M & 4.2 & & 1.38 & $\mathrm{R}$ & 0.11 & $\mathrm{R}$ & 13 & $\mathrm{~S}$ \\
\hline 16. & ZW-4/III & & $40-80$ & 1 & 82 & 17 & Sil & 4.9 & M & 4.2 & & 1.63 & $\mathrm{R}$ & 0.13 & $\mathrm{R}$ & 13 & $S$ \\
\hline 17. & ZW-50/I & $\begin{array}{l}\text { Typic } \\
\text { Udorthents }\end{array}$ & $0-15$ & 7 & 75 & 18 & Sil & 4.7 & M & 4.4 & & 0.98 & SR & 0.07 & SR & 14 & S \\
\hline 18. & ZW-19/I & Typic & $0-25$ & 14 & 61 & 25 & Sil & 5.2 & $\mathrm{M}$ & 4.2 & & 1.66 & $\mathrm{R}$ & 0.15 & $\mathrm{R}$ & 11 & $S$ \\
\hline 19. & ZW-19/II & Eutrudepts & $25-40$ & 12 & 67 & 21 & Sil & 4.9 & $\mathrm{M}$ & 4.1 & & 0.70 & SR & 0.07 & SR & 10 & $\mathrm{R}$ \\
\hline 20. & ZW-19/III & & $40-80$ & 19 & 68 & 13 & Sil & 4.8 & M & 4.2 & & 0.49 & SR & 0.05 & SR & 10 & $\mathrm{R}$ \\
\hline 21. & ZW-34/I & Typic & $0-30$ & 29 & 41 & 30 & $\mathrm{CL}$ & 5.0 & $M$ & 4.5 & & 1.19 & $\mathrm{R}$ & 0.10 & $\mathrm{R}$ & 12 & $S$ \\
\hline 22. & ZW-34/II & epts & $30-60$ & 32 & 43 & 25 & $\mathrm{CL}$ & 6.3 & AM & 6.1 & & 0.81 & SR & 0.08 & SR & 10 & $\mathrm{R}$ \\
\hline 23. & ZW-34/III & & $60-75$ & 34 & 36 & 30 & $\mathrm{CL}$ & 7.6 & $\mathrm{~N}$ & 7.3 & & 0.53 & SR & 0.05 & SR & 11 & $\mathrm{R}$ \\
\hline 24. & ZW-55/I & Typic & $0-25$ & 7 & 80 & 13 & Sil & 5.1 & M & 4.8 & & 1.56 & $\mathrm{R}$ & 0.11 & $\mathrm{R}$ & 14 & S \\
\hline 25. & ZW-55/II & Ec & $25-50$ & 6 & 81 & 13 & Sil & 5.5 & $M$ & 5.0 & & 1.00 & $\mathrm{R}$ & 0.08 & SR & 13 & S \\
\hline 26. & ZW-56/I & & $0-30$ & 63 & 21 & 16 & Sil & 5.6 & AM & 4.8 & & 0.58 & SR & 0.05 & SR & 12 & $\mathrm{~S}$ \\
\hline 27. & ZW-21/I & Typic & $0-15$ & 52 & 33 & 15 & L & 4.6 & M & 4.0 & & 1.14 & $\mathrm{R}$ & 0.12 & $\mathrm{R}$ & 10 & $\mathrm{R}$ \\
\hline 28. & ZW-21/II & EL & $15-30$ & 48 & 36 & 16 & L & 4.5 & M & 4.1 & & 0.63 & SR & 0.05 & SR & 13 & S \\
\hline 29. & ZW-21/III & & $30-80$ & 54 & 33 & 13 & SL & 4.6 & M & 4.0 & & 0.11 & SR & 0.01 & SR & 11 & S \\
\hline
\end{tabular}




\section{Lampiran 3 Tabel: Hasil Analisis Tanah Pulau Buru}

\begin{tabular}{|c|c|c|c|c|c|c|c|c|c|c|c|c|c|c|c|}
\hline \multirow[t]{3}{*}{ No. } & \multirow{3}{*}{$\begin{array}{l}\mathrm{N} \circ \mathrm{m} \text { or } \\
\text { Contoh }\end{array}$} & \multirow{3}{*}{$\begin{array}{l}\text { Klasifikasi } \\
\text { Tanah }\end{array}$} & \multirow{3}{*}{$\begin{array}{l}\text { Keda- } \\
\text { laman } \\
\text { Tanah }\end{array}$} & \multicolumn{12}{|c|}{ Sampel Tanah } \\
\hline & & & & \multicolumn{4}{|c|}{$\mathrm{HCl}(\mathrm{mg} / 100 \mathrm{~g})$} & \multicolumn{2}{|c|}{ Olsen (ppm) } & \multicolumn{2}{|c|}{ Bray 1 (ppm) } & \multicolumn{4}{|c|}{ Nilai Tukar Kation Cmol/kg } \\
\hline & & & & $\mathrm{P}_{2} \mathrm{O}_{5}$ & Kelas & $\mathrm{K}_{2} \mathrm{O}$ & Kelas & $\mathrm{P}_{2} \mathrm{O}_{5}$ & Kelas & $\mathrm{P}_{2} \mathrm{O}_{5}$ & Kelas & $\mathrm{ca}$ & Kelas & $\mathrm{Mg}$ & Kelas \\
\hline & P. Buru & & & & & & & & & & & & & & \\
\hline 1. & ZW-43/I & & $0-15$ & 58 & $\mathrm{~T}$ & 241 & ST & - & & 13.8 & T & 2.69 & $\mathrm{R}$ & 0.54 & $\mathrm{R}$ \\
\hline 2. & ZW-43/II & Tyрic & $15-25$ & 53 & $\mathrm{~T}$ & 290 & ST & - & & 11.9 & T & 2.07 & $\mathrm{R}$ & 0.37 & $\mathrm{R}$ \\
\hline 3. & ZW-43/III & Fluvaquents & $25-60$ & 28 & $\mathrm{~S}$ & 338 & ST & - & & 3.8 & SR & 1.37 & SR & 0.19 & SR \\
\hline 4. & ZW-36/I & $\begin{array}{l}\text { Lithic } \\
\text { Udorthents }\end{array}$ & $0-15$ & 44 & $\mathrm{~T}$ & 28 & $S$ & 27 & ST & - & & 22.75 & ST & 14.04 & ST \\
\hline 5 & ZW-38/I & $\begin{array}{l}\text { Lithic } \\
\text { Udorthents }\end{array}$ & $0-25$ & 18 & $\mathrm{R}$ & 65 & ST & 5 & $\mathrm{R}$ & - & & 9.26 & $\mathrm{~S}$ & 2.97 & $\mathrm{~T}$ \\
\hline 6. & ZW-39/I & Lithic & $0-15$ & 8 & SR & 8 & SR & - & & 5.7 & $\mathrm{R}$ & 0.28 & SR & 0.08 & SR \\
\hline 7. & ZW-39/II & Udorthents & $15-30$ & 4 & SR & 10 & $\mathrm{R}$ & - & & 1.1 & SR & 0.19 & SR & 0.00 & SR \\
\hline 8. & ZW-10/I & Typic & $0-20$ & 20 & $\mathrm{R}$ & 10 & $\mathrm{R}$ & 7 & & - & & 24.70 & ST & 3.60 & $\mathrm{~T}$ \\
\hline 9. & ZW-10/II & Udorthents & $20-70$ & 12 & SR & 11 & $\mathrm{R}$ & 3 & & - & & 20.40 & $\mathrm{~T}$ & 1.27 & $S$ \\
\hline 10 & ZW-22/I & $\begin{array}{l}\text { Typic } \\
\text { Udorthents }\end{array}$ & $0-15$ & 12 & SR & 15 & $\mathrm{R}$ & - & & 14.4 & $\mathrm{~T}$ & 1.54 & SR & 0.60 & $\mathrm{R}$ \\
\hline 11. & ZW-29/I & & $0-20$ & 31 & $S$ & 43 & $T$ & - & & 1.9 & SR & 0.91 & SR & 0.62 & $\mathrm{R}$ \\
\hline 12. & ZW-29/II & Typic & $20-50$ & 22 & $S$ & 56 & T & - & & 1.9 & SR & 0.57 & SR & 0.41 & $\mathrm{R}$ \\
\hline 13. & ZW-29/III & Udorthents & $50-90$ & 18 & $\mathrm{R}$ & 57 & $\mathrm{~T}$ & - & & 1.5 & SR & 0.38 & SR & 0.94 & $\mathrm{R}$ \\
\hline 14. & ZW-4/I & & $0-20$ & 49 & $\mathrm{~T}$ & 148 & ST & - & & 12.4 & T & 1.74 & $\mathrm{SR}$ & 0.46 & $\mathrm{R}$ \\
\hline 15. & ZW-4/II & Typic & $20-40$ & 64 & ST & 146 & ST & - & & 18.0 & ST & 3.02 & $\mathrm{R}$ & 1.12 & $S$ \\
\hline 16. & ZW-4/III & Udorthents & $40-80$ & 59 & $\mathrm{~T}$ & 198 & ST & - & & 4.5 & $\mathrm{R}$ & 2.64 & $\mathrm{R}$ & 1.43 & $S$ \\
\hline 17. & ZW-50/I & $\begin{array}{l}\text { Typic } \\
\text { Udorthents }\end{array}$ & $0-15$ & 88 & ST & 30 & $\mathrm{~S}$ & - & & 6.3 & $\mathrm{R}$ & 2.77 & $\mathrm{R}$ & 1.40 & $S$ \\
\hline 18. & ZW-19/I & & $0-25$ & 25 & $S$ & 35 & $S$ & - & & 2.6 & SR & 4.71 & $\mathrm{R}$ & 1.22 & $S$ \\
\hline 19. & ZW-19/II & Typic & $25-40$ & 22 & $S$ & 38 & $\mathrm{~S}$ & - & & 1.7 & SR & 1.00 & SR & 0.23 & SR \\
\hline 20. & ZW-19/III & Eutrudepts & $40-80$ & 25 & $S$ & 36 & $S$ & - & & 2.5 & SR & 0.96 & SR & 0.21 & SR \\
\hline 21. & ZW-34/I & & $0-30$ & 19 & $\mathrm{R}$ & 85 & ST & - & & 8.4 & S & 8.03 & $S$ & 0.88 & $\mathrm{R}$ \\
\hline 22. & ZW-34/II & Typic & $30-60$ & 21 & $\mathrm{R}$ & 92 & ST & 11 & $S$ & - & & 13.93 & $\mathrm{~T}$ & 0.54 & $\mathrm{R}$ \\
\hline 23. & ZW-34/III & Eutrudepts & $60-75$ & 21 & $S$ & 103 & ST & 5 & SR & - & & 18.78 & ST & 0.22 & $\mathrm{SR}$ \\
\hline 24. & ZW-55/I & & $0-25$ & 23 & $S$ & 75 & ST & - & S & 5.7 & & 10.57 & $\mathrm{~S}$ & 0.99 & $\mathrm{R}$ \\
\hline 25. & ZW-55/II & Typic & $25-50$ & 18 & $\mathrm{R}$ & 103 & ST & 11 & & - & $\mathrm{R}$ & 13.63 & $\mathrm{~T}$ & 0.85 & $\mathrm{R}$ \\
\hline 26. & ZW-56/I & Eutrudepts & $0-30$ & 11 & SR & 104 & ST & 8 & $\mathrm{R}$ & 0.0 & SR & 3.23 & $\mathrm{R}$ & 0.43 & $\mathrm{R}$ \\
\hline 27. & ZW-21/I & & $0-15$ & 24 & $S$ & 38 & $S$ & - & & 6.8 & $\mathrm{R}$ & 1.39 & SR & 1.06 & $\mathrm{R}$ \\
\hline 28. & ZW-21/II & Typic & $15-30$ & 29 & $S$ & 44 & T & - & & 5.1 & $\mathrm{R}$ & 0.81 & SR & 0.41 & $\mathrm{R}$ \\
\hline 29. & ZW-21/III & Eutrudepts & $30-80$ & 19 & $\mathrm{R}$ & 27 & $\mathrm{~s}$ & - & & 3.4 & SR & 0.48 & SR & 0.29 & $\mathrm{SR}$ \\
\hline
\end{tabular}



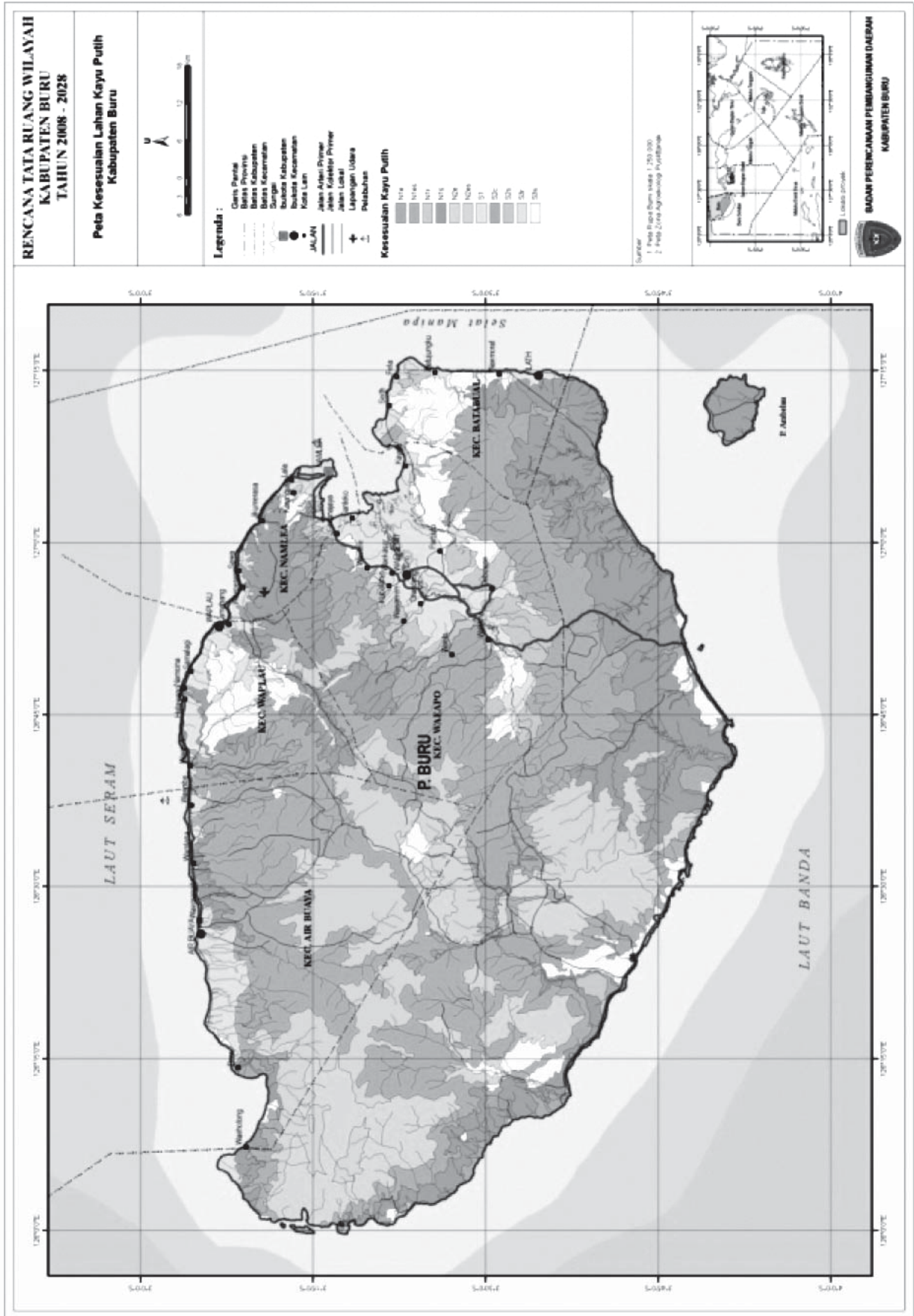

Evaluasi Kesesuaian Lahan ..J. Tek. Ling.11 (1): 105 - 116 